\author{
Aleksandra Gardian \\ Uniwersytet Kardynała Stefana Wyszyńskiego w Warszawie \\ ORCID 0000-0003-3508-3064 \\ DOI https://doi.org/10.21697/ucs.2021.27.1.06
}

\title{
SPRAWOZDANIE ZE SPOTKANIA Z CYKLU „ECONOMIC LUNCHTIME SEMINARS” PT. MOLDOVA'S COMPETITIVENESS: TENDENCIES, CHALLENGES AND SMES DIFFICULTIES
}

Zgodnie z tradycją ugruntowaną na Wydziale Społeczno-Ekonomicznym UKSW w czwartek, 28 stycznia 2021 r., odbyło się kolejne spotkanie z cyklu „Economic Lunchtime Seminars”, które - po sukcesie grudniowego seminarium - było wyczekiwane nie tylko przez organizatorów i pracowników naukowo-dydaktycznych Wydziału, lecz również przez studentów. Frekwencja na spotkaniu była co prawda mniejsza, ale zapewne było to spowodowane zbliżającą się sesją egzaminacyjną, do której przygotowanie się było dla studentów priorytetem.

Tak jak w przypadku grudniowego spotkania, do połączenia w trybie zdalnym wykorzystano platformę Zoom. Zagranicznym gościem, który wygłosił prelekcję zatytułowaną Moldova's competitiveness: tendencies, challenges and SMEs difficulties, był prof. Alexandru Stratan, dyrektor National Institute for Economic Research. Moderatorem spotkania był dr inż. Piotr Komorowski z Katedry Finansów, który na początku przywitał wszystkich uczestników spotkania, w tym m.in. gości z Fondazione Istituto Teseo we Włoszech, oraz przedstawił prelegenta.

Nie może dziwić, że część merytoryczną rozpoczęto od omówienia wpływu pandemii COVID-19 na gospodarkę narodową Mołdawii, społeczno-ekonomiczne skutki rozprzestrzeniania się tego wirusa absorbują bowiem obecnie uwagę nie tylko wielu ekonomistów, lecz również przedstawicieli innych nauk społecznych, w tym socjologów.

Profesor A. Stratan zaprezentował uczestnikom kilkadziesiąt interesujących wykresów, które uświadamiały, jak ogromne piętno odcisnął koronawirus na gospodarce Mołdawii, a komentarze prelegenta tylko wzmacniały to przekonanie. Z załamaniem ogólnogospodarczym, które dobrze obrazują wskaźniki makroekonomiczne, wiążą się poważne problemy społeczne wynikające z jednej strony z trudności finansowych spowodowanych spadkiem dochodów, a z drugiej strony z ograniczenia kontaktów międzyludzkich. Nasilił się przy tym problem wykluczenia społecznego - przykładowo wiele osób, w szczególności starszych i uboższych, zostało w dużej mierze pozbawionych możliwości utrzymywania kontaktów z innymi ludźmi za sprawą braku urządzeń telekomunikacyjnych lub dostępu do internetu bądź braku umiejętności korzystania z nich.

Profesor pogrupował skutki gospodarcze pandemii na te, które odnoszą się do kanałów dostaw, finansów i popytu zagregowanego (określając je jako wewnętrzne), i te, które odnoszą się handlu zagranicznego i migracji (określając je jako zewnętrzne). Podkreślił, że od początku lat dwutysięcznych do wybuchu pandemii stopa wzrostu gospodarczego w Mołdawii nigdy nie osiągnęła tak wysokich ujemnych wartości jak w 2020 r., kiedy to zanotowano spadek PKB aż o 7,5\%. Co prawda w 2009 r., czyli w okresie światowego kryzysu, wskaźnik ten również osiągnął dramatycznie wysoką wartość ujemną, ale wówczas był to spadek PKB o 6\%. Potwierdza to zatrważającą skalę załamania gospodarczego wywołanego COVID-19.

Restrykcje wprowadzone w celu przeciwdziałania rozprzestrzenianiu się koronawirusa bardzo dotkliwie odbiły się na przedsiębiorstwach produkcyjnych - nastąpiło przerwanie ciągłości dostaw, a większość inwestycji została odłożona w czasie. W ogromne trudności koronawirus wepchną także sektor usług. Silny spadek odnotowano nie tylko w handlu, lecz także w transporcie i usługach magazynowania. Według prelegenta ma to związek ze spadkiem importu i eksportu towarów, który był konsekwencją ograniczeń w przemieszczaniu się.

$\mathrm{Z}$ powodu pandemii bardzo ucierpiał także sektor finansów publicznych. Konieczne okazało się zrewidowanie budżetu państwa. Więcej środków przeznaczono na ochronę zdrowia oraz wsparcie biznesu. 
Kryzys spowodowany pandemią istotnie wpłynął również na rynek pracy. Pensje pracowników zatrudnionych w niektórych branżach były wypłacane z opóźnieniem lub musiały zostać zmniejszone. Pracownicy wykorzystywali zaległe urlopy wypoczynkowe. Nierzadko jednak pracodawcy dążyli do rozwiązania stosunku pracy w drodze porozumienia stron. W sposób naturalny przełożyło się to na wzrost bezrobocia.

Zdalny tryb pracy i nauki oraz zamknięcie istotnych dla nawiązywania i utrzymywania relacji międzyludzkich gałęzi gospodarki, jak gastronomia czy rozrywka, to czynniki, które - nie tylko w Mołdawii - doprowadziły do dotkliwych skutków społecznych.

Profesor zwrócił uwagę, że na samym początku pandemii, do 20 marca 2020 r., zaobserwowano lawinowy (albo gwałtowny) powrót do ojczyzny osób pracujących za granicą. W niektórych dniach granice przekraczało ponad 15000 ludzi, ale z czasem dzienna liczba osób przyjeżdżających ustabilizowała się na dużo niższym poziomie i obecnie maksymalnie wynosi 3000 .

Druga część seminarium dotyczyła trendów i wyzwań w odniesieniu do konkurencyjności mołdawskiej gospodarki. Na przestrzeni ostatniej dekady wzrost gospodarczy w Mołdawii był mniejszy, niż zakładano. Według danych z 2018 r. Mołdawia, zaraz po Ukrainie, zajmuje drugie miejsce w niechlubnym rankingu europejskich krajów z najniższym PKB per capita (mimo że w latach 2014-2018 wskaźnik ten, wprawdzie nieznacznie, ale wzrastał).

Prelegent nie miał wątpliwości, że kryzys wywołany przez pandemię koronawirusa pogłębił problemy ekonomiczne Mołdawii. Nie nastraja to optymistycznie, jeśli chodzi o prognozy wzrostu poziomu życia obywateli. Niemal każdy obywatel Mołdawii doświadcza ubóstwa, jednak najgorzej sytuacja wygląda na obszarach wiejskich. Nierówności społeczne między obszarami wiejskimi i miejskimi są widoczne zwłaszcza przy porównaniach dostępu do ochrony zdrowia i możliwości znalezienia zatrudnienia. Uwarunkowania te mają bardzo istotne znaczenie nie tylko dla komfortu życia, lecz również dla rozwoju relacji międzyludzkich. Obywatele Mołdawii, którzy w obawie przed zakażeniem koronawirusem wrócili do swoich domów rodzinnych na obszarach wiejskich, skazani są na lokalny rynek pracy, a długotrwałe kłopoty ze znalezieniem źródła utrzymania mogą prowadzić do wykluczenia społecznego.

Następnie prof. A. Stratan omówił sytuację w sektorze małych i średnich przedsiębiorstw. Począwszy od 1994 r., w Mołdawii wypracowano kilka programów, których zadaniem jest wspieranie tej grupy przedsiębiorstw. Największym problemem, dotykającym aż 75-90\% przedsiębiorstw, jest brak źródeł finansowania albo duże kłopoty z ich pozyskaniem. Od początku pandemii koronawirusa zbankrutowało aż $10 \%$ mołdawskich przedsiębiorców, a 59\% ma poważne trudności z bieżącym zaspokojeniem wierzycieli. Nietrudno się domyślić, że koronawirus najbardziej skomplikował sytuację finansową tych branż, które z powodu zamrożenia gospodarki musiały zostać zamknięte.

Wiele problemów sektora małych i średnich przedsiębiorstw wynika z trudności w uzyskaniu pozwoleń na prowadzenie działalności gospodarczej, ich źródła tkwią także w systemie podatkowym oraz częstych zmianach legislacyjnych. Małe i średnie przedsiębiorstwa nie mają natomiast kłopotów z pozyskaniem i utrzymaniem siły roboczej, ponieważ problem bezrobocia w Mołdawii, pogłębiony w okresie pandemii koronawirusa, sprawia, iż każdy wakat jest szybko obsadzany.

Prelekcja zagranicznego gościa trwała prawie półtorej godziny. Po niej była możliwość zadawania pytań. Rozpoczęła się wówczas intensywna dyskusja, której przedmiotem był m.in. system bankowy w Mołdawii. Profesor A. Stratan wyjaśnił, że aktualnie w Mołdawii funkcjonuje 11 banków i wszystkie one mają w całości albo w części kapitał zagraniczny.

Zapytany o bieżące wydarzenia polityczne w Mołdawii, profesor wspomniał o wyborach prezydenckich, które odbyły się w listopadzie 2020 r. Decyzją wyborców stanowisko prezydenta objęła Maia Sandu, pokonując dotychczasowego prezydenta Igora Dodona. Obecna prezydent bardzo łatwo wygrała wybory, mimo że początkowo nie zapowiadało się na zwycięstwo tej reprezentantki partii opozycyjnej.

Interesującym wątkiem w dyskusji była ocena szans Mołdawii na przystąpienie do Unii Europejskiej. Zdaniem profesora do akcesji Mołdawii do UE nie dojdzie na pewno w przeciągu najbliższych 10 lat, ponieważ obywatele Mołdawii w większości są temu przeciwni, a wola społeczeństwa wyrażona w referendum ogólnokrajowym jest niezbędnym warunkiem akcesji. Co więcej, profesor uważa, że w wielu obszarach Mołdawia nie spełnia kryteriów warunkujących przystąpienie do UE, a przy takim stanie rzeczy nawet 
zachęty ze strony UE niewiele znaczą. Profesor wyraził ubolewanie nad tym faktem, widząc, jak korzystnie wstąpienie do UE wpłynęło na kraje Europy Środkowo-Wschodniej, z Polską na czele. Zwrócił uwagę, że główne towary eksportowe Mołdawii to produkty przemysłowe i artykuły rolno-spożywcze, a wiele produktów pochodzenia zwierzęcego, a także owoce, warzywa oraz wina, bardzo trudno jest wprowadzić na rynek europejski. Przynależność do UE zagwarantowałaby Mołdawii swobodny dostęp do rynku wewnętrznego, co sprzyjałoby intensyfikacji wymiany handlowej i - w opinii prelegenta - znacząco przyczyniłoby się do poprawy sytuacji gospodarczej kraju.

Wątek społecznej akceptacji dla integracji europejskiej kontynuował dr P. Komorowski, który zauważył, że stosunkowo duża liczba Polaków obecnie nie jest zadowolona z członkostwa w UE, mimo że w 2003 r., w referendum akcesyjnym, wyrazili akceptację dla wstąpienia do UE. Polacy przede wszystkim są przeciwni przyjęciu waluty euro, choć członkostwo w unii walutowej przynosi wiele korzyści. Doktor P. Komorowski podkreślił, że obecnie bardzo trudno przewidzieć, jakie państwa będą wchodziły w skład UE w kolejnych dekadach, co najlepiej widać na przykładzie Wielkiej Brytanii. Choć niewątpliwie należy ona do grupy krajów zamożnych, wysoko rozwiniętych, jej obywatele opowiedzieli się za wyjściem z UE w przekonaniu, że członkostwo w tym ugrupowaniu ogranicza niezależność państwa i generuje więcej kosztów niż korzyści. W mojej opinii akcesja Mołdawii do UE dawałaby szansę uporania się z wieloma problemami ekonomicznymi, sprzyjając przy tym zmniejszeniu nierówności społecznych.

$\mathrm{Na}$ koniec dr P. Komorowski podziękował prelegentowi za ciekawy wykład, aktywnym uczestnikom za wartościową dyskusję, a pozostałym słuchaczom - za uwagę. Zasygnalizował, że kolejne seminaria być może będą koncentrowały się na analogicznych kwestiach, ale będą dotyczyły innych państw. Taka formuła prelekcji pozwala w szczególności na syntetyczne przedstawienie najważniejszych, aktualnych problemów społeczno-gospodarczych danego kraju oraz przedyskutowanie środków zaradczych podejmowanych w ramach bieżącej polityki gospodarczej. 